\title{
HEMATOLOGY, BLOOD GASES AND BIOCHEMISTRY PROFILES OF WILD-NESTING SEA TURTLES IN TERENGGANU, MALAYSIA
}

\author{
SYAMSYAHIDAH SAMSOL ${ }^{1,4}$, MOHD EFFENDY ABD WAHID ${ }^{2}$, TSUNG-HSIEN LI ${ }^{3}$ \\ and MOHD UZAIR RUSLI ${ }^{*}$ \\ ${ }^{I}$ Faculty of Science \& Marine Environment, Universiti Malaysia Terengganu, Terengganu \\ ${ }^{2}$ Faculty of Fisheries \& Food Sciences, Universiti Malaysia Terengganu, Terengganu \\ ${ }^{3}$ National Museum of Marine Biology \& Aquarium (NMMBA), Taiwan \\ ${ }^{4}$ Sea Turtle Research Unit (SEATRU), Institute of Oceanography \& Environment, \\ Universiti Malaysia Terengganu, Terengganu \\ *E-mail:uzair@umt.edu.my
}

Accepted 9 October 2020, Published online 25 December 2020

\begin{abstract}
Chelonia mydas is an endangered marine species globally, which its reference blood parameters intervals have been published for some group populations, but baseline health status values are lacking from Malaysia. This study aims to better understand the hematology, biochemical, and blood gas of a wild-nesting green turtle population in the South China Sea. The health status of nesting turtles at the Chagar Hutang Turtle Sanctuary, Pulau Redang, were performed on different individuals, (26 females laid one nest and 2 females laid two nests). A portable handheld blood analyzer (iSTAT) used in the field to obtain immediate results of $\mathrm{pH}$, lactate, $\mathrm{pO}_{2}, \mathrm{pCO}_{2}, \mathrm{HCO}_{3}{ }^{-}, \mathrm{Hct}, \mathrm{Hb}, \mathrm{Na}, \mathrm{K}, \mathrm{iCa}$, and glucose levels in blood samples, while standard laboratory hematology techniques were conducted at Universiti Malaysia Terengganu (UMT) for red and white blood cell counts. The results for all blood analytes (except $\mathrm{Na}, \mathrm{iCa}$, and hematology values) were not within the healthy index range for wild turtles, compared to previous studies from different geographic populations. Therefore, the results of this current study help to develop a baseline profile of healthy wild-nesting turtles as a global reference for detecting abnormalities in blood chemistry and the health status of turtle populations worldwide.
\end{abstract}

Key words: Blood biochemistry, health assessment, endangered species, conservation, South China Sea

\section{INTRODUCTION}

Sea turtles are marine creatures that are well adapted to the ocean, but females are still tied to the land and will eventually come ashore for nesting activity. Mating event occurs offshore in the early phases of the nesting season, oftentimes nearby the nesting beaches, and nesting females come ashore alone at night time to lay their eggs. They possess natal homing characteristics, return to their birth general region, and previous nesting grounds to lay eggs (Bowel, 1995 in Miller (1997). Green sea turtle (Chelonia mydas) is currently listed as an endangered marine chelonian (IUCN, 2010) with a circum-tropical distribution. Within the South China Sea region, Malaysia has the highest density of nesting beaches compared to other neighboring countries, large nesting populations of green turtles

* To whom correspondence should be addressed. can mainly found in Sabah and Sarawak's Turtle Islands, whereas in Peninsular Malaysia, it in the states of Terengganu (Pulau Redang, Pulau Perhentian, Kemaman and Kerteh) (Chan, 2006).

Green turtle populations are facing various major threats; 1) habitat destruction, 2) pollution, $3)$ disease, 4) consumption of meat and eggs by local populations, 5) death due to fishing gear entanglement, and 6) consumption of plastics and other anthropogenic materials (Denkinger et al., 2013). Blood biochemical and hematology parameters are useful diagnostic tools in animal management, the population stock for wildlife biology, and species conservation (Aguirre \& Lutz, 2004; Lewbart et al., 2014). Reference intervals (RIs) for sea turtles in Aguirre and Lutz (2004), Casalé et al. (2009), Labrada-Martagón et al. (2010a), Anderson et al. (2011a), and Zhang et al. (2011) used as guidelines for this study. Wild sea turtle blood gas values have been reported and analyzed 
(Hamann et al., 2006; Wolf et al., 2008), but very limited studies have combined hematology, blood gases, and biochemical parameters from the same geographic sub-population of sea turtles. This present study appears to be the first health assessment study evaluates selected hematology, blood gases, and biochemical parameters of wild-nesting green turtles from one of the highest density nesting beaches in the South China Sea.

\section{MATERIALS AND METHODS}

\section{Ethics statement}

Outputs mainly focused on the maternal health status of endangered species to save our natural heritage from extinction. The research was conducted under Permit Park. Tr.2214 Jld 2 (12) by Department of Fisheries (DOF) Terengganu and University Animal Ethics Approval Reference Number is UMT/KJEPHT/2019/37.

\section{Study site}

Sample collected (late July - early September 2019) at Chagar Hutang Turtle Sanctuary (5 48.778' N; $103^{\circ} 0.502^{\prime}$ E), Pulau Redang, Terengganu, Malaysia (Figure 1), managed by the Sea Turtle Research Unit (SEATRU), Universiti Malaysia Terengganu (UMT). Chagar Hutang was recorded to have the highest nesting density in Peninsular Malaysia during 2018 and provides the best opportunity in the region to sample multiple nesting females during the peak nesting season.

\section{Data collection}

Sea turtle nest monitoring was conducted to collect blood samples from wild-nesting turtles for hematological and blood biochemistry profiling. A total of 30 blood samples from 26 individual turtles nested once and two individuals each nested twice were obtained in this study. Blood sample collections were drawn after oviposition (laying eggs) as it may bring further consequences upon disturbance during the process.

\section{Physical examinations and morphometric data}

Physical examinations of an individual are rated by 1) a visual body examination and 2) body condition score (BCS) (Norton \& Wyneken, 2015), charted from a score of 1 (emaciated) to 5 (obese) (Li et al., 2015). A visual body examination describes lesions or injuries alongside any presence of epibiotic organisms. As for morphometric data, curved carapace lengths (CCL) and curved carapace widths $(\mathrm{CCW})$ were obtained by using a measuring tape, whereas weight was recorded by applying a manual crane scale concept and a handheld infrared thermometer used to read temperature values (Burns et al., 2015).

\section{Blood samples}

Approximately $5.0 \mathrm{~mL}$ of blood samples were humanely collected from the dorsal jugular vein (Dutton, 1996) as followed in Standard Operational Procedures while handling reptiles (Wyneken, 2001), using a 21-gauge needle and heparinized tubes attached to a $6.0 \mathrm{~mL}$ syringe. Antiseptic agent

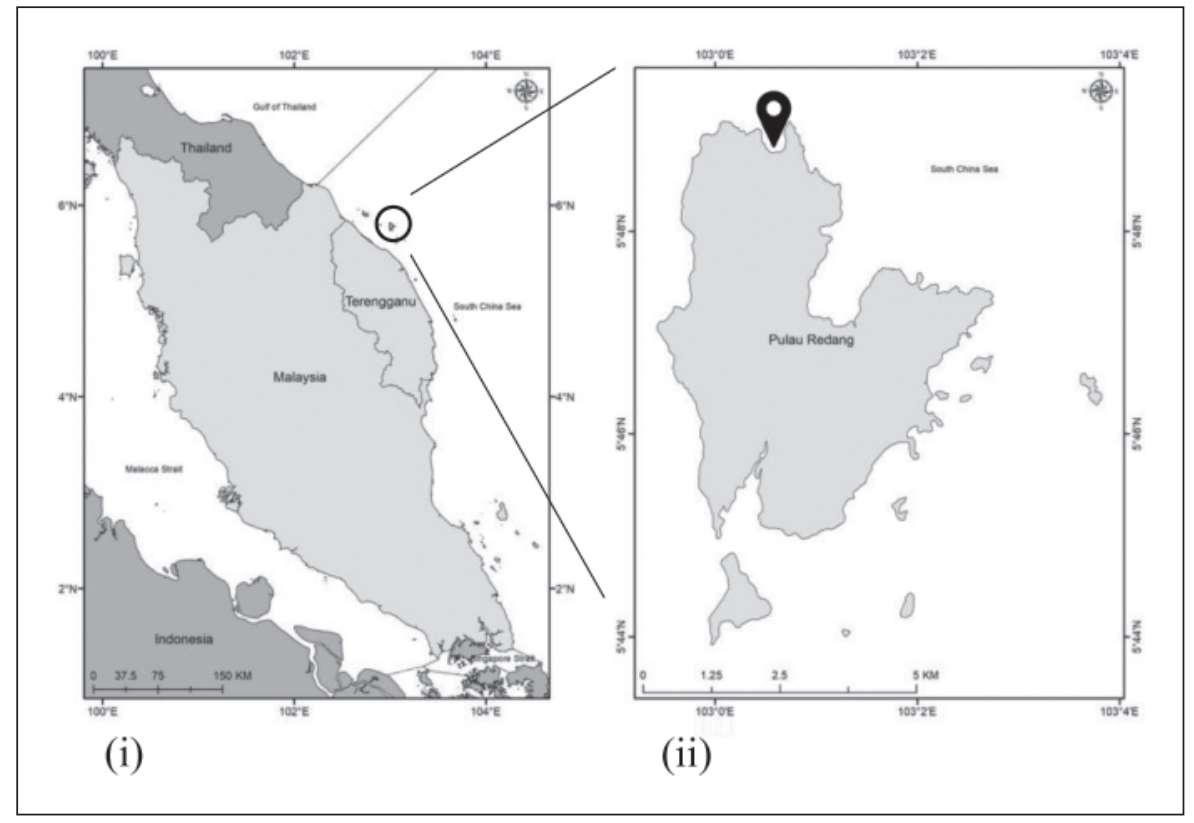

Fig. 1. Map of Peninsular Malaysia, where the location of (i) Terengganu and (ii) Chagar Hutang Turtle Sanctuary in Pulau Redang. All the data required for this were collected along the 350 meters beach during nesting activity. 
(iodine solution) applied to the puncture site of the skin to disinfect the area prior-to and after-blood sample collection (Li et al., 2015). Blood samples obtained were immediately placed in lithium heparin tubes and shaken well before divided into sub-samples for further hematological and blood biochemistry analyses. Samples were stored in a portable DISON electronic refrigerated mini box with a constant temperature at $8^{\circ} \mathrm{C}$ for field usage. Ice cubes were then added into the box to maintain the temperature while transporting the samples to the laboratory at The Taaras Beach \& Spa Resort, Pulau Redang for laboratory analysis.

\section{Hematological values, blood gases, and bio- chemistry profiles \\ The iSTAT Portable Clinical Analyzer (Heska} Corporation) with CG-4+ and CG-8+ cartridges were used to measure the levels of blood gases, electrolytes, and biochemistry parameters with only a few drops $(0.095 \mathrm{~mL})$ of blood, allowed to obtain reliable results in-situ on nesting turtles. The parameters of $\mathrm{pH}$, lactate (Lac), the partial pressure of oxygen $\left(\mathrm{pO}_{2}\right)$, the partial pressure of carbon dioxide $\left(\mathrm{pCO}_{2}\right)$, bicarbonate $\left(\mathrm{HCO}_{3}^{-}\right)$, hematocrit (Hct), hemoglobin $(\mathrm{Hb})$, sodium $(\mathrm{Na})$, potassium $(\mathrm{K})$, ionized calcium (iCa), and glucose (Glu) were measured and recorded within 10 min obtaining blood samples. Packed Cell Volume (PCV) values were determined by high-speed centrifugation of blood-filled microhematocrit tubes at $12000 \mathrm{rpm}$ for 5 min (Nardini et al., 2013). Differential white blood cell (WBC) counts were manually performed on blood films stained with Wright's solution using estimation of WBC count (Flower et al., 2015). Leukocytes were manually categorized using a compound light microscope into the following groups: heterophils (HETE), lymphocytes (LYM), monocytes (MONO), eosinophils (EOS), and basophils (BASO) (Li et al., 2015).

\section{Data analysis}

The overlapping values of the $\mathrm{CG}-4+$ and CG-8+ cartridges from iSTAT blood chemistry results, which consisted of all analytes except for lactate, were compared using student t-tests. All statistical analyses were done using IBM SPSS statistical software version 25 .

\section{RESULTS AND DISCUSSION}

In Table 1, the mean CCL for turtles in this study was $96.2 \mathrm{~cm}$ (ranges $84 \mathrm{~cm}-107.2 \mathrm{~cm}$ ) and the mean CCW was $84.5 \mathrm{~cm}$ (ranges $67 \mathrm{~cm}-94 \mathrm{~cm}$ ). Mean body weight was $93.9 \mathrm{~kg}$ (ranges $79.3 \mathrm{~kg}-121.5 \mathrm{~kg}$ ) and mean body temperature was $27.8^{\circ} \mathrm{C}$ (ranges $26.1^{\circ} \mathrm{C}-30.1^{\circ} \mathrm{C}$ ). All turtles determined to be clinically healthy with BCS ranging between 3 and 4 , indicated the normal range. This study is relatable with previous findings of Chan (2013), who reported in Pulau Redang that the annual average of CCL ranged from $98.9 \mathrm{~cm}$ to $100.9 \mathrm{~cm}$. Meanwhile, the mean CCL of nesting populations in Heron Island and Rain Island, Australia where it is $107 \mathrm{~cm}$ and $106 \mathrm{~cm}$ respectively (Limpus et al., 2009) and in the Turtle Islands, Philippines with $99.5 \mathrm{~cm}$ (Seminoff et al., 2015). Such differences might due to regional differences depending on biochemical parameters, food availability, and composition of the diet (Labrada-Martagón et al., 2010a). Thus, the physical examinations and morphometric data able to act as an evaluating tool for body conditions of wildnesting green turtles.

Blood biochemical values obtained from $\mathrm{CG}-4+$ and CG-8+ cartridges were consistent and no significant differences statistically, hence the blood gases and biochemistry (Table 2) and hematological (Table 3) values reported were based on the first cartridge run for all samples (CG-8+). Some resulted in slightly smaller sample sizes due to the iSTAT blood analyzer unable to detect the values because of the unsuitable condition of the blood, temperature for the equipment, or the cartridges. The reported blood parameters for this study were not similar to Reference Intervals (RIs) of healthy wild green turtles (Flint et al., 2010; Labrada-Martagón et al., 2010; Lewbart et al., 2014) due to the RIs referred were populations of pre or post-nesting season, where our study prior on wild-nesting green turtles.

Comparatively, this study determined wildnesting green turtles to have slightly lower $\mathrm{HCO}_{3}{ }^{-}$, $\mathrm{pH}, \mathrm{pO}_{2}$, and $\mathrm{Hb}$ levels while $\mathrm{pCO}_{2}, \mathrm{~K}$, Glu, Hct, and Lac were slightly higher values within RIs of previous studies. Meanwhile, only $\mathrm{Na}$ and $\mathrm{iCa}$ of this study were reported to be within the published RIs and such differences might due to the current state of the individuals (wild turtles of all ages during pre or post-nesting season) (Anderson et al., 2011a; Lewbart et al., 2014). Concentrations of sodium $(\mathrm{Na})$, a primary electrolyte in maintaining water in one's body, and potassium (K), a primary source of food intake, depended upon the frequency of nesting events, where both analytes decrease with increasing nesting event counts as they are in a fasting state during the nesting season (Honarvar et al., 2011). The lactate levels, an index of muscle injury, in this study ranges 8.08 to $20 \mathrm{mmol} / \mathrm{L}$ indicated the turtles were facing muscle injury due to high muscle activity during the nesting process, as compared to the RIs in wild green turtles (life stage: immature and mature) is between 0.80 to $8.73 \mathrm{mmol} / \mathrm{L}$ (Lewbart et al., 2014). Nevertheless, the blood gases and biochemical values in this study portray the normal range of analyte concentrations of wildnesting green turtles. 
Table 1. Detailed morphometric data consists of 28 individuals with a turtle identification number (Turtle ID), body weight (BW), curved carapace length (CCL), curved carapace width (CCW), body temperature (BTemp), and body condition score (BCS) of wild-nesting green turtles at Chagar Hutang Turtle Sanctuary, Pulau Redang

\begin{tabular}{|c|c|c|c|c|c|}
\hline Turtle ID & BW (kg) & $\mathrm{CCL}(\mathrm{cm})$ & $\mathrm{CCW}(\mathrm{cm})$ & BTemp $\left({ }^{\circ} \mathrm{C}\right)$ & BCS \\
\hline \multirow[t]{2}{*}{ 1993G019* } & 79.7 & 90.0 & 81.0 & 26.6 & 4 \\
\hline & 79.3 & 90.0 & 81.0 & 27.4 & 4 \\
\hline 2009 G059 & 95.2 & 95.8 & 81.8 & 27.1 & 3 \\
\hline 2010 G097 & 109.8 & 99.5 & 89.2 & 27.8 & 4 \\
\hline $2013 G 160$ & 82.5 & 97.0 & 83.0 & 28.1 & 4 \\
\hline 2013G169 & 84.0 & 90.0 & 86.0 & 28.6 & 3 \\
\hline 2014G073 & 100.5 & 104.5 & 93.5 & 28.3 & 3 \\
\hline 2014G090 & 112.5 & 107.2 & 91.3 & 28.0 & 3 \\
\hline \multirow[t]{2}{*}{$2014 \mathrm{G} 121^{*}$} & 93.9 & 96.0 & 83.9 & 27.3 & 4 \\
\hline & 98.2 & 96.0 & 84.0 & 28.7 & 3 \\
\hline $2016 G 236$ & 121.5 & 101.5 & 67.0 & 28.2 & 3 \\
\hline $2016 G 317$ & 84.7 & 94.0 & 84.0 & 28.0 & 4 \\
\hline 2019G205 & 90.1 & 96.0 & 83.3 & 27.9 & 3 \\
\hline 2019G211 & 82.1 & 92.0 & 84.0 & 28.2 & 4 \\
\hline 2019G225 & 84.7 & 94.0 & 79.0 & 26.9 & 4 \\
\hline 2019G233 & 103.1 & 101.6 & 89.0 & 30.1 & 3 \\
\hline 2019G239 & 90.8 & 95.2 & 82.5 & 27.9 & 4 \\
\hline $2019 G 247$ & 99.2 & 97.0 & 83.0 & 26.5 & 3 \\
\hline $2019 G 250$ & 91.1 & 90.0 & 81.0 & 28.0 & 3 \\
\hline $2019 G 253$ & 98.5 & 96.0 & 84.0 & 25.5 & 4 \\
\hline $2019 G 259$ & 82.1 & 90.0 & 85.0 & 27.6 & 3 \\
\hline $2019 G 263$ & 80.3 & 92.0 & 82.0 & 26.1 & 4 \\
\hline 2019G264 & 55.8 & 84.0 & 71.0 & 26.1 & 4 \\
\hline 2019G270 & 95.2 & 101.8 & 85.5 & 28.7 & 4 \\
\hline 2019G275 & 104.6 & 100.0 & 87.5 & 28.4 & 4 \\
\hline 2019G281 & 116.8 & 102.0 & 94.0 & 28.4 & 4 \\
\hline 2019G282 & 112.5 & 102.0 & 89.0 & 28.4 & 4 \\
\hline 2019G283 & 81.3 & 95.0 & 87.0 & 28.1 & 4 \\
\hline 2019G284 & 102.1 & 96.0 & 94.0 & 29.0 & 3 \\
\hline $2019 G 285$ & 106.2 & 101.0 & 88.0 & 29.1 & 3 \\
\hline
\end{tabular}

* $=$ individual that nested twice during the sampling period.

Table 2. Mean, standard deviation, and range for blood gases and biochemical values for wild-nesting green turtles at Chagar Hutang Turtle Sanctuary, Pulau Redang

\begin{tabular}{lccccc}
\hline Analyte & $\mathrm{n}$ & Mean & $\mathrm{SD}$ & Min & Max \\
\hline $\mathrm{Na}(\mathrm{mmol} / \mathrm{L})$ & 30 & 134.80 & 13.51 & 101.00 & 146.00 \\
$\mathrm{~K}(\mathrm{mmol} / \mathrm{L})$ & 30 & 5.70 & 2.01 & 3.60 & 9.00 \\
$\mathrm{iCa}(\mathrm{mmol} / \mathrm{L})$ & 30 & 0.81 & 0.30 & 0.25 & 1.21 \\
$\mathrm{Glu}(\mathrm{Umg} / \mathrm{dl})$ & 19 & 79.79 & 14.37 & 61.00 & 108.00 \\
$\mathrm{Lac}(\mathrm{mmol} / \mathrm{L})$ & 28 & 13.05 & 3.36 & 8.08 & 20.00 \\
$\mathrm{pH}$ & 30 & 7.15 & 0.20 & 6.57 & 7.54 \\
$\mathrm{pCO}_{2}(\mathrm{mmHg})$ & 23 & 75.23 & 16.21 & 52.80 & 119.10 \\
$\mathrm{pO}_{2}(\mathrm{mmHg})$ & 19 & 96.63 & 36.13 & 60.00 & 175.00 \\
$\mathrm{BE}(\mathrm{mmol} / \mathrm{L})$ & 25 & -0.20 & 5.88 & -12.00 & 11.00 \\
$\mathrm{HCO}{ }_{3}^{-}(\mathrm{mmol} / \mathrm{L})$ & 25 & 28.08 & 4.64 & 17.00 & 38.00 \\
$\mathrm{TCO}_{2}(\mathrm{mmol} / \mathrm{L})$ & 25 & 30.44 & 4.60 & 19.00 & 40.00 \\
$\mathrm{sO}_{2}(\mathrm{mmol} / \mathrm{L})$ & 24 & 87.04 & 10.26 & 66.00 & 100.00 \\
\hline
\end{tabular}

$\mathrm{Na}=$ Sodium $. \mathrm{K}=$ Potassium $. \mathrm{iCa}=$ Ionized Carbon. $\mathrm{Glu}=$ Glucose $. \mathrm{pCO}_{2}=$ Partial Carbon Dioxide. $\mathrm{pO}_{2}=$ Partial Oxygen. $\mathrm{BE}=$ Base Excess. $\mathrm{HCO}_{3}{ }^{-}=$Bicarbonate. $\mathrm{TCO}_{2}=$ Total Carbon Dioxide. $\mathrm{sO}_{2}=$ Oxygen Saturation.

The reported hematology values obtained consistent with published ranges for healthy nesting and wild green turtles (Flint et al., 2010; Anderson et al., 2011a; Gibbons et al., 2013). The hematological values depended on the diet, environmental conditions (Flint et al., 2010), and home range (Page-Karjian et al., 2014). In this study, the PCV describes an earlier detection of one's health condition, ranges $14 \%$ to $50 \%$ that is similar to previous studies for healthy green turtles in the 
Table 3. Mean, standard deviation, and range for manually analyzed hematology values of wild-nesting green turtles at Chagar Hutang Turtle Sanctuary, Pulau Redang

\begin{tabular}{lccccc}
\hline Analytes & $\mathrm{n}$ & Mean & SD & Min & Max \\
\hline PCV $(\%)$ & 30 & 31.27 & 8.79 & 14.00 & 50.00 \\
WBC $\left(\times 10^{9} / \mathrm{L}\right)$ & 30 & 1.65 & 0.87 & 0.30 & 4.40 \\
LYM $\left(\times 10^{9} / \mathrm{L}\right)$ & 30 & 0.33 & 0.16 & 0.10 & 0.60 \\
MONO $\left(\times 10^{9} / \mathrm{L}\right)$ & 30 & 0.07 & 0.06 & 0.01 & 0.20 \\
HETE $\left(\times 10^{9} / \mathrm{L}\right)$ & 30 & 1.58 & 0.90 & 0.20 & 3.40 \\
EOS $\left(\times 10^{9} / \mathrm{L}\right)$ & 30 & 0.60 & 0.41 & 0.10 & 1.30 \\
BASO $\left(\times 10^{9} / \mathrm{L}\right)$ & 30 & 0.0000003 & 0.0000005 & 0.00 & 0.000001 \\
Hct $(\mathrm{L} / \mathrm{L})$ & 29 & 21.31 & 3.68 & 15.00 & 30.00 \\
Hb $(\mathrm{g} / \mathrm{L})$ & 28 & 7.37 & 1.14 & 5.00 & 10.00 \\
\hline
\end{tabular}

$\mathrm{PCV}=$ Packed Cell per Volume. $\mathrm{WBC}=$ White Blood Cells. LYM $=$ Lymphocytes. MONO = Monocytes. HETE $=$ Heterophils. EOS $=$ Eosinophils. $\mathrm{BASO}=$ Basophils. $\mathrm{Hct}=$ Hematocrit. $\mathrm{Hb}=$ Hemoglobin.

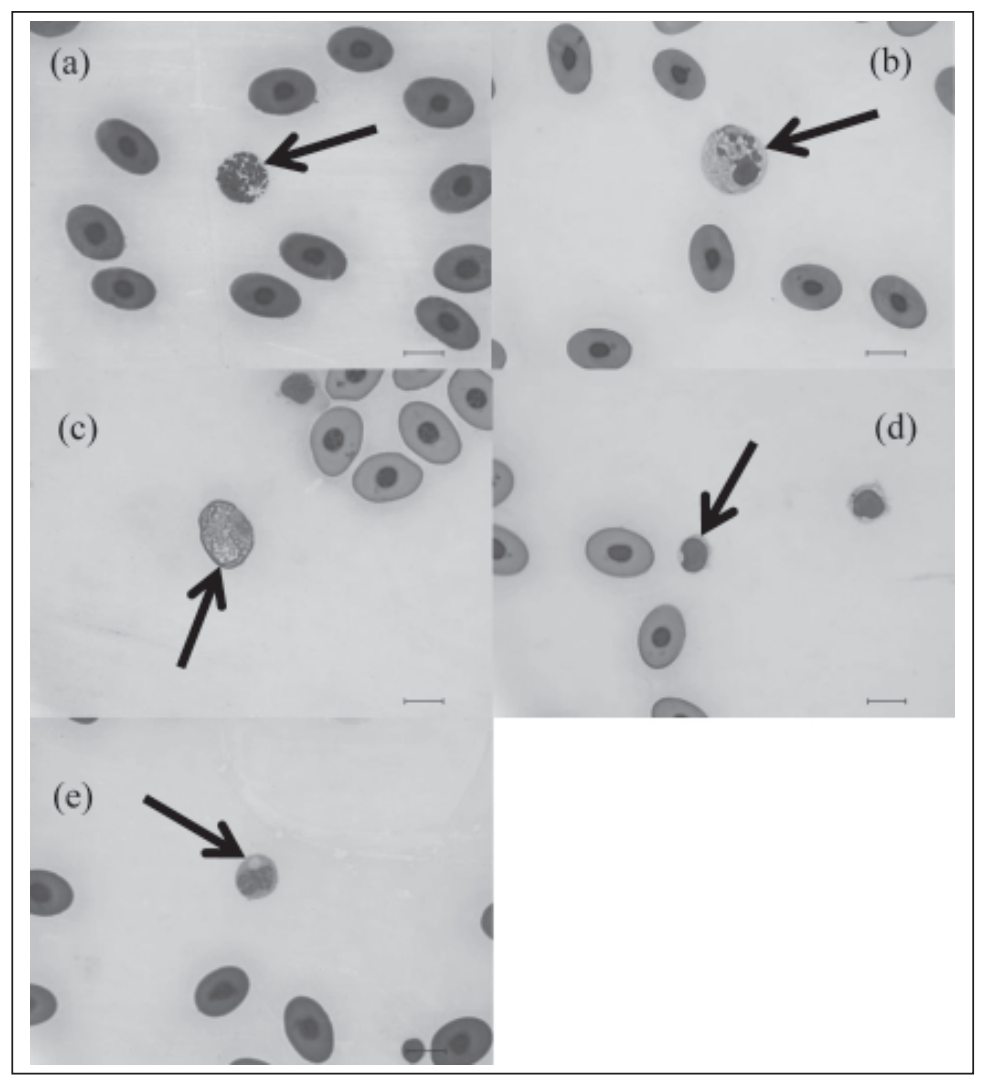

Fig. 2. Microscopic images of white blood cells (Wright's stain) under 1000× magnification with a scale bar of $10 \mu \mathrm{m}$ : (a) Basophil (BASO), (b) Eosinophil (EOS), (c) Heterophil (HETE), (d) Lymphocyte (LYM), and (e) Monocyte (MONO). The blood was collected from wild-nesting green turtles at Chagar Hutang Turtle Sanctuary, Pulau Redang.

Galapagos (Lewbart et al., 2014), and United Arab Emirates (Samour et al., 1988). Thus, the wildnesting green turtles in Chagar Hutang beach were deduced to be in good health condition. The decrement of PCV level is related to increasing amounts of nesting events throughout a season (Day et al., 2007; Whiting et al., 2007), where it correlated to the physiological stress of folliculogenesis and nesting.
Manual performed blood profiling found heterophils (Figure 2c), a large, eosinophilic fusiform cytoplasmic granule with a pinkish cytoplasm, is the most abundant leukocyte with a mean value of $1.58 \times 10^{9} / \mathrm{L}$ (Table 3 ). Eosinophil (Figure 2b), round eosinophilic and cytoplasmic granules, the second abundant in our study with a mean of $0.60 \times 10^{9} / \mathrm{L}$. Basophils (Figure 2a) identified by a large and round granule deeply 
stained in purple. Lymphocyte (Figure 2d) appeared to have a small cytoplasm stained in blue, while monocyte (Figure 2e) consisted of cytoplasm stained in blue-grey, which seems slightly opaque and may contain vacuoles or fine dust. Lymphocytes are reported being the most abundant type of white blood cells in some reptilian and amphibians (Campbell, 1995) as it offers various purposes in one's body such as giving an immediate reaction to foreign invaders. However, this study recorded heterophils as the most abundant leukocytes, where it might due to the occurrence of inflammatory diseases (muscle stress, tissue injury, microbial and parasitic infections) (Campbell, 2006; Sykes \& Klaphake, 2008). Hence, our reported values were as such because the turtles were high in muscle stress caused by nesting activities. Also, the number of basophils in this study was scarce in healthy wildnesting green turtles, which is relatable to a previous study reported on green turtles by Work et al. (1998).

\section{CONCLUSION}

This study reports the first baseline data of hematology, blood gases, and biochemistry profiles for wild-nesting green turtle population in Terengganu, Malaysia, which represents the normal blood biochemistry of a significant portion of the sea turtle population in the vicinity of the South China Sea region. Comparison of the blood parameters of unhealthy turtles with the reported profiles of this study can act as guidelines towards giving recommendations for rehabilitation and the design of therapies for this species of turtles, as health assessments are important especially on endangered species. In the near future, it is hoped that studies on the elucidating physiological changes of wild-nesting green turtles for characterizing differences between clutches in a season can be investigated, as it enhances our understanding of the possible association between blood chemistry profile and reproductive outputs.

\section{ACKNOWLEDGEMENTS}

We wish to thank the following people and organizations for their support and assistance with this project: Team members of Sea Turtle Research Unit, UMT's Marine Biology Undergraduates, Institute of Marine Biotechnology, The Taaras Beach \& Spa Resort in Pulau Redang, and Department of Fisheries in Malaysia. This work was supported and funded by the Fundamental Grant Research Scheme (FRGS Vot 59488), The Government of Malaysia.

\section{REFERENCES}

Aguirre, A.A. \& Lutz, P. 2004. Sea turtles as sentinels of marine ecosystem health: is fibropapillomatosis an indicator? EcoHealth, 1(3): 275-283.

Anderson, E.T., Harms, C.A., Stringer, E.M. \& Cluse, W.M. 2011a. Evaluation of hematology and serum biochemistry of cold-stunned green sea turtles (Chelonia mydas) in North Carolina, USA. Journal of Zoo and Wildlife Medicine, 42(2): 247-255.

Burns, T.J., McCafferty, D.J. \& Kennedy, M. 2015. Core and body surface temperatures of nesting leatherback turtles (Dermochelys coriacea). Journal of Thermal Biology, 5(1): 15-22.

Campbell, T.W. 1995. Avian hematology. In: Avian Hematology and Cytology. T.W. Campbell (Ed.). Iowa State University Press, Ames, IA. pp. 7-11.

Campbell, T.W. 2006. Chapter 28 - Clinical Pathology of Reptiles. In: Reptile Medicine and Surgery. D.R. Mader (Ed.). Elsevier Saunders. pp.453-470.

Casalé, A.B., Camacho, M., López-Jurado, L.F., María, J. \& Orós, J. 2009. Comparative study of hematologic and plasma biochemical variables in eastern Atlantic juvenile and adult nesting loggerhead sea turtles (Caretta caretta). Veterinary Clinical Pathology, 38: 213-218.

Chan, E.H. 2013. A report on the first 16 years of a long-term marine turtle conservation project in Malaysia. Asian Journal of Conservation Biology, 2(2): 129-135.

Day, R.D., Segars, A.L., Arendt, M.D., Lee, A.M. \& Peden-Adams, M.M. 2007. Relationship of blood mercury levels to health parameters in the loggerhead sea turtle (Caretta caretta). Environmental Health Perspectives, 115: 14211428.

Denkinger, J., Parra, M., Munoz, J.P., Carrasco, C., Murillo, J.C., Espinosa, E., Rubianes, F. \& Koc, V. 2013. Are boat strikes a threat to sea turtles in the Galapagos Marine Reserve? Ocean Coastal Management, 80: 29-35.

Dutton, P.H. 1996. Methods for collection and preservation of samples for sea turtle genetic studies. In: Proceedings of the International Symposium on Sea Turtle Genetics. B.W. Bowen and W.N. Witzell (Eds.). NOAA Technical Memorandum. pp. 17-24.

Flint, M., Morton, J.M., Limpus, C.J., Patterson-Kane, J.C., Murray, P.J. \& Mills, P.C. 2010. Development and application of biochemical and haematological reference intervals to identify unhealthy green sea turtles (Chelonia mydas). Veterinary Journal, 185: 299-304. 
Flower, J.E., Norton, T.M., Andrews, K.M., Nelson Jr, S.E., Parker, C.E., Romero, L.M. \& Mitchell, M.A. 2015. Baseline plasma corticosterone, haematological, and biochemical results in nesting and rehabilitating loggerhead sea turtles (Caretta caretta). Conservation Physiology, 3: cov003.

Gibbons, P.M., Klaphake, E. \& Carpenter, J.W. 2013. Reptiles. In: Exotic Animal Formulary. J. Carpenter and C. Marion (Eds.). Elsevier Saunders. pp. 84-170.

Hamann, M., Schauble, C.S., Simon, T. \& Evans, S. 2006. Demographic and health parameters of green sea turtles Chelonia mydas foraging in the Gulf of Carpentaria, Australia. Endangered Species Research, 2: 81-88.

Honarvar, S., Brodsky, M., Fitzgerald, D., Rosenthal, K. \& Hearn, G. 2011. Changes in plasma chemistry and reproductive output of nesting leatherbacks. Herpetologica, 67(3): 222-235.

IUCN. 2010. IUCN red list of threatened species [WWW Document]. URL http://www.iucnredlist. org (accessed 21.12.19).

Labrada-Martagon, V., Mendez-Rodriguez, L.C., Gardner, S.C., Lopez-Castro, M. \& ZentenoSavin, T. 2010a. Health indices of the green turtle (Chelonia mydas) along the Pacific coast of Baja California Sur, Mexico. Chelonian Conservation Biology, 9(2): 162-172.

Lewbart, G.A., Hirschfeld, M., Denkinger, J., Vasco, K., Guevara, N., García, J., Muñoz, J. \& Lohmann, K.J. 2014. Blood gases, biochemistry, and hematology of Galapagos green turtles (Chelonia mydas). PLoS ONE, 9(5): e96487.

Li, T.H., Chang, C.C., Cheng, I.J. \& Lin, S.C. 2015. Development of a Summarized Health Index (SHI) for use in predicting survival in sea turtles. PLoS ONE, 10(3): e0120796.

Limpus, C.J. 2008. A biological review of an Australian marine turtles. Environmental Protection Agency, Brisbane.

Miller, J.D. 1997. Reproduction in sea turtles. In: The biology of sea turtles. P.L. Lutz and J.A. Musick (Eds.). Boca Raton: CRC Press. pp. 5181

Nardini, G., Leopardi, S. \& Bielli, M. 2013. Clinical hematology in reptilian species. Veterinary Clinics of North America Exotic Animal Practice, 16: 1-30.
Norton, T. \& Wyneken, J. 2015. Body condition scoring (BCS) of the sea turtle [WWW Document]. URL https://lafeber.com/vet/bodycondition-scoring-the-sea-turtle/ (accessed 15.01.20).

Page-Karjian, A., Norton, T., Krimer, P., Groner, M., Nelson, S. \& Gottdenker, N. 2014. Factors influencing survivorship in rehabilitating green sea turtles (Chelonia mydas) with fibropapillomatosis. Journal of Zoo and Wildlife Medicine, 45: 507-519.

Samour, J., Hewlett, J., Silvanose, C., Hasbun, C. \& Al-Ghais, S. 1988. Normal haematology of free-living green sea turtles (Chelonia mydas) from the United Arab Emirates. Comparative Haematology International, 8: 102-107.

Seminoff, J.A., Allen, C.D., Balazs, G.H., Dutton, P.H., Eguchi, T., Haas, H.L., Hargrove, S.A., Jensen, M.P., Klemm, D.L., Lauritsen, A.M., MacPherson, S.L., Opay, P., Possardt, E.E., Pultz, S.L., Seney, E.E., Van Houtan, K.S. \& Waples R.S. 2015. Status review of the green turtle (Chelonia mydas) under the US Endangered Species Act. NOAA Technical Memorandum, NOAANMFS-SWFSC-539. 571 pp.

Sykes, J.M. \& Klaphake, E. 2008. Reptile hematology. Veterinary Clinics of North America Exotic Animal Practice, 11: 481-500.

Whiting, S.D., Guinea, M.L., Limpus, C.J. \& Fomiatti, K. 2007. Blood chemistry reference values for two ecologically distinct populations of foraging green turtles, eastern Indian Ocean. Comparative Clinical Pathology, 16: 109-118.

Wolf, K.N., Harms, C.A. \& Beasley, J.F. 2008. Evaluation of five clinical chemistry analyzers for use in health assessment in sea turtles. Journal of the American Veterinary Medical Association, 233: 470-475.

Work, T.M., Raskin, R.E., Balazs, G.H. \& Whittaker, S.D. 1998. Morphologic and cytochemical characteristics of blood cells from Hawaiian green turtles. American Journal of Veterinary Research, 59: 1252-1257.

Wyneken, J. 2001. The Anatomy of Sea Turtles. U.S. Department of Commerce NOAA Technical Memorandum NMFS-SEFSC-470, 1-172 pp.

Zhang, F., Gu, H. \& Li, P. 2011. A review of chelonian hematology. Asian Herpetological Research, 2(1): 12-20. 
